\title{
Effect of Algerian Varieties Dates on Glycemic, Arterial Blood Pressure and Satiety Responses
}

\author{
Gourchala Freha ${ }^{1 *}$, Mihoub Fatma ${ }^{1}$, Derradj Meriem² and Henchiri Cherifa ${ }^{2}$ \\ 'Faculty of Natural Sciences and Life, Ibn Khaldoun Tiaret University, Algeria; \\ frehagourchala@gmail.com \\ ${ }^{2}$ Faculties of Sciences, Badji Mokhtar Annaba University, Algeria; \\ mihoub2@yahoo.fr, meriem.derradj@gmail.com, cherifa_henchiri@yahoo.fr
}

\begin{abstract}
The purpose of our study is to determine the Glycemic Indexes (GIs) of three Algerians varieties of dates in healthy subjects evaluate the satiety and effect on arterial pressure after their consumption. We have first documented the chemical composition of the dates. 10 healthy subjects consumed the dates (carbohydrates content of $50 \mathrm{~g}$ ) in order to determine the GIs. The responses of glycaemia were monitored during two hours after the dates taking and compared to the reference glucose. In a randomized trial, 20 healthy adults consumed the dates after $12 \mathrm{~h}$ of fast. We reported the level of satiety on a Visual Analog Scale for $2 \mathrm{~h}$ further to the ingestion of the dates. Furthermore, 28 normotensives and 45 hypertensive individuals ingested the three varieties in randomized order during 21 days to assess their impact on the Pressure Arterial Systolic (PAS) and Pressure Arterial Diastolic (PAD). We noted significant differences $(\mathrm{p}<0.05)$ for the different fractions of sugars, soluble fibers, polyphenols, $\mathrm{K}^{+}, \mathrm{Mg}^{2+}$. The low GIs are denoted among 44.31-52.35, deducting a moderate impact on blood glucose level. The dates reduced hunger and increased satiety. Our varieties studied following their ingestion induced a significant hypotensive activity $(\mathrm{p}<0.05)$ on the PAS and, PAD from hypertensive subjects.
\end{abstract}

Keywords: Algerians Dates, Blood Pressure, Glycemic Index, Humans Subjects, Satiety

\section{Introduction}

Dates palm, Phoenix dactylifera L. fruits, can participate for physiological regulation by their diverse composition such as vitamins, minerals, fibers, proteins, lipids, antioxidants and fructose. They are also a carbohydrate food $^{1,2}$ and may affect blood sugar levels. It is important to optimize their consumption in quantity and quality. The concept of Glycemic Index (GI) has been set up in $1981^{3}$ and allows classifying aliments containing sugars by their capacity to influence on glycaemia after their consumption ${ }^{4}$. They are graded over $0-100$ scale according to their capacity to release glucose in blood: 100 being gold-standard for certain food like glucose or bread. At same amount of sugar, aliments with a high GI, entail in marked fluctuations in blood glucose levels, with low GI do less ${ }^{5}$. Further proofs tend to figure out that the regimen who's the GIs are low, contribute to prevent late diabetes and coronary diseases likely because of the abatement of insulin needs ${ }^{6}$. They give a satiety feeling ${ }^{7}$, which controls putting on weight, and consequently the obesity which leads to high blood pressure or diabetes, but healthy individuals' too. The diabetes and high blood pressure prevalence magnitude is becoming higher and higher in Algeria; which displays over 3 million diabetic individuals according to $7^{\text {th }}$ international congress in October 2014, of the "Association des médecins de l'Oranie pour la prevalence cardio-vasculaire" (Amoprec). The last public statistical statement in November 2014 of the "Société Algérienned'Hypertension Artérielle" (SAHA, Algerian Society of Arterial Hypertension) also states that 35\% of more than 20 years old Algerians already suffer of high blood pressure. Facing this health problem, clinical and nutritional recommendations target good alimentary practices, such as coming back to wholesome aliment consumption like fruits and vegetables, and advice to temperate meals with the wealth of proteins, sugars including dates; a fact which are not yet "anchored in the

${ }^{*}$ Author for correspondence 
habits" in Algeria, pointing out that "diabetic regimens" only doesn't concern diabetics persons, but all. The dates are a fundamental part of the diet in arid and semi-arid regions of Algeria. This habit is declining very fast probably due to the presence of paramount content of sugar. The current nutritional education also opposes the traditional use of dates due to the rise of diabetes and high blood pressure patients. However, many other studies figure out that GI of dates is moderately low. Other components such as polyphenols, potassium, magnesium, sodium, and vitamins found at low variable concentrations in date may be responsible of the following biological properties. Polyphenols protect against oxidative stress ${ }^{9}$, and possess some anti-high blood pressure effects ${ }^{10}$. The considerable amount of potassium and magnesium has protective role in cardiovascular diseases in general and high blood pressure in particular ${ }^{11}$ Ascorbic acid and pyridoxine are able to reduce blood pressure ${ }^{12,13}$. In our study, we have determined the glycemic index of three varieties of dates H'mira, Tinissine and Deglet Noor commonly eaten and appreciated in our communities and evaluate the satiety, in healthy individuals and their regular consumption effects on the arterial blood pressure. Our purposes are to measure the postprandial GI of the three varieties, to ratify from human the measure of low GI in reference to glucose (control) and to test if the daily consumption of dates (7 dates) regularly alter the arterial pressure from hypertensive and normotensive subjects.

\section{Materials and Methods}

Three varieties of dates in "tamr" stage are obtained from the farmers. The choice of varieties is based on the fact of their consumption importance by the Algerians and their availability on the territory markets: H'mira, which came from Ghardaïa (about $600 \mathrm{~km}$ from south of Algiers) is a cheaper, readily gained and consumed variety in all the Algerian territory; and Tinissine variety available and highly consumed only in the producing areas; whereas the very appreciated Deglet Noor variety, plus its availability in all the Algerian territory is very expensive and exported to the European countries. These two last varieties came from Adrar (south Algeria). The samples were collected from same place of each region. 10kg of each variety were used for experimentation. Each sample was cleaned and placed in polyethylene bags with labels, and stored in a refrigerator until analyses.

\subsection{Physicochemical Analyses of Dates}

For each date variety, total sugars have been determined by Dubois method and Bertrand method ${ }^{14}$ has been realized for anti-oxidizing sugars. Saccharose rate is got by following formula: $\%$ Saccharose $=\%$ total sugar - $\%$ total reducers sugars. The method used for free glucose is made of oxidation of glucose aldehyde function to gluconate ion in alkaline solvent containing an excess iodine ion. Free fructose is measured by DNS method; method Kjeldahl ${ }^{15}$ for proteins, insoluble fibers ${ }^{16}$, soluble fibers ${ }^{17}$, water rate by drying at $103 \pm 2^{\circ} \mathrm{C}$ of ground sample on capsule until getting constant dried weight ${ }^{14}$; $(\% \mathrm{H}$, humidity $=\mathrm{m}_{1}-\mathrm{m}_{2} / \mathrm{p} \times 100$. The $\mathrm{pH}$ measurement has been done by $\mathrm{pH}$-meter of Karl Kolb trademark; total ash is obtained by incineration. Sample drying at $105^{\circ} \mathrm{C}$ during 24 hours is followed by calcination in mitten furnace for 5 hours at $500^{\circ} \mathrm{C}^{18}$; OM, organic matter $=\mathrm{m}_{1}-\mathrm{m}_{2} / \mathrm{p} \times$ 100; \%Ash $=100-\% \mathrm{OM})$. The sodium, potassium and magnesium documentation is done by atomic absorption spectrophotometer; the rates are established by standard curves.

\subsection{Phytochemical Screening}

The phytochemical screening and components characterization have been done for aqueous and methanol/water $(80 \mathrm{v} / 20 \mathrm{v})$ with drawing ${ }^{19}$. To ratify different chemical sets by colorimetric reactions according to Ciulei ${ }^{20}$; we constraint the alkaloids detection by Dragendorff reagent, polyphenols and tannins by $\mathrm{FeCl}_{3}$ test, koumarines by pair ammoniac and UV exposition test and flavonoids by Shibata test. The documentation of total polyphenols rate is figured out by Folin-Ciocalteau reagent according to Singleton and Rossi method ${ }^{21}$ using gallic acid as standard. The coloration result whose maximum absorption is between 725 and $750 \mathrm{~nm}$ is proportional to polyphenols amount from plant extract. The results are displayed in mg of Gallic Acid Equivalent (GAE)/100g of fresh weight. The flavonoids amount is appreciated with the method described by Lamaison and Carnat ${ }^{22}$ using Quercitrin like standard, the coloration produced whose absorbance is $430 \mathrm{~nm}$ is proportional to flavonoids amount. These results are exhibited in $\mathrm{mg}$ of quercitrin/100g of plant matter fresh weight.

\subsection{Study 1. Glycemic Index}

This study is relied on FAO recommendation and the 
ISO 26642. In 2010, the randomization has been stated according to Brouns et al. suggestions ${ }^{23}$.

\subsubsection{Subjects}

Ten voluntary individuals (seven female sexes) aged from 19 to 38 years with the $\mathrm{BMI}=21.6 \mathrm{~kg} / \mathrm{m}^{2}$, a good health and zero sugar metabolism perturbation (as we know), nonsmoking disposition and no drug therapies are including in our study. Individuals only considered to have normal sugar metabolism are retained to monitor the postprandial glycemia relying on the Induced Hyperglycemia by Oral Route (IHOR); which is realized during pre-inclusion visit on overnight fasted subjects (glycaemia $<1.1 \mathrm{~g} / \mathrm{l}$; $6.1 \mathrm{mmol} / \mathrm{l})^{24}$. It was asked to subjects to do not practice any novel physical activity absent in customs.

\subsubsection{Experimental Protocol}

Each participant was encountered for seven visits. The pre-inclusion visit booked for IHOR exam is separated with experimental stage by 15 days: visit 1: inclusion phase, experimental session $n^{\circ} 1$ where participants have ingested $50 \mathrm{~g}$ of referent control product (glucose) in water solution; visit 2: experimental session $\mathrm{n}^{\circ} 2$ has had each participant to ingest the experiment product (dates containing a corresponding amount of $50 \mathrm{~g}$ of carbohydrate not fiber); visit 3: at experimental session $\mathrm{n}^{\circ} 3$ we have got an iterative procedure by reattributing the same amount of glucose as at visit 1 ; at visit 4 and visit 5 (experimental sessions 4 and 5 ) the reiterated gests of visit 2 have been done and last visit 2 has repeated the control (experimental session 6 as in visits 1 and 3). For both controls and experimentation, subjects had eaten nothing ten hours as the experiments were done.

The first notation of glycaemia, at time $\ll \mathrm{T}=-5 \mathrm{~min}$ $\gg$, is got before to give products; then the subjects were relaxed before to ingest either glucose or dates at $\mathrm{T}=0$. The blood swabs were obtained at $\mathrm{t}=0,15,30,45,60$, 90 and 120 min from participants' fingers to document glycaemia thanks to the glucometer (Roche Accu-Chek Active), which is based on the action of glucose oxidase. The glycemic indexes have been determined by further areas ratios under the comparative plots of dates and glucose. Glycemic Index (GI) is computed that way: GI= (IAUC test Food/IAUC standard reference Food) x 100.

\subsection{Study 2. The Dates Effect on Satiety}

\subsubsection{Subjects}

We have organized our study randomly. Twenty voluntary male students from University of Tiaret who were aged between 19 and 26 years old and had BMI $=20 \mathrm{~kg} / \mathrm{m}^{2}$, good health and no drug treatment, non-smoker and no-physical activities during the experimentation were registered within the study.

\subsubsection{Experimental Protocol}

To compare the four aliments effects, each individual (having eaten nothing since $12 \mathrm{~h}$ ) was seen four times separated with two days between two visits. The three varieties of dates (H'mira, Deglet Noor and Tinissine) and $100 \mathrm{~g}$ of bread from baker's shop associated with coffee (usual breakfast of young Algerians). Bread and different dates were consumed at each of the four visits. Our questioner sheet accounts four questions to evaluate subjective feeling related to appetite (desire to eat, hungry, repletion and propensity to food consumption), which were how strength do you desire to eat? (Slight-strong); how do you feel hungry? (Not of all hungry-as never felt); how do you feel repletion? (Not of all-very replete); what amount of food do you think you could ingest? (Mere nothing-some great quantity). The participants were asked to signal their condition on a visual scale analogy of $150 \mathrm{~mm}$ by placing a vertical line on the sensation felt ${ }^{25}$. The VAS has been measured after twelve hours having eaten nothing and all 30, 60, 90 and 120 minutes, following the consumption.

\subsection{Study 3. The Dates Effect on Arterial Blood Pressure}

\subsubsection{Subjects}

The study has included 73 voluntary adults aged more than 22 years old and who didn't undergo antihypertensive medicine. Each individual had been checked for the systolic and diastolic arterial pressures averages over six assessments during three screening visits to be divided in two groups:

45 subjects ( 28 female sexes, mean age $=50$ years old $)$ 
had slight arterial high blood pressure with PAS from 140 to $159 \mathrm{Hg} \mathrm{mm}$ or PAD from 89 to $99 \mathrm{Hg} \mathrm{mm}$ according to $\mathrm{WHO}^{26}$, mean BMI of entire sample is $24.43 \pm 3.63 \mathrm{Kg} /$ $\mathrm{m}^{2}\left(24.77 \pm 4.19 \mathrm{Kg} / \mathrm{m}^{2}\right.$ for female and $24.06 \pm 3.11 \mathrm{Kg} / \mathrm{m}^{2}$ for male). $30 \%$ of samples are sedentary, $70 \%$ practice a moderate physical activity and 04 individuals are smokers (male). 28 subjects (18 female) are normotensive with $\mathrm{PA}<130 / 85 \mathrm{Hg} \mathrm{mm}^{5}$, mean age equal 48 years old, mean BMI of $22.1 \pm 2.31 \mathrm{Kg} / \mathrm{m}^{2}, 17 \%$ sedentary people, $83 \%$ practice a moderate physical activity, 04 smokers. For the two samples, the consumption of dates is more spread during Ramadhan and, what allowed us to conclude that biochemical modification on the biological parameters of the sample come from our regimen.

\subsubsection{Experimental Protocol}

The trial is issued for three phases. Along each phase, the subjects consumed $62 \mathrm{~g}$ of H'mira per day, or $65 \mathrm{~g}$ of Deglet Noor or 63.5g of Tinissine (corresponding to 7 stoned dates) during 15 days for each variety in order of randomized concession: 15 days of drainage is slipped in between ingestions of dates varieties. The blood pressures are noted before and after dates' consumption. The dates are consumed by each participant before breakfast, slowly date after date without interruption. The subjects who do not possess teeth or tooth decay, and no having finished their 15 sets during the 15 days are discontinued from the study: these main criteria of exclusion, including pregnancy or breastfeeding (women), are setup for factors discrediting arterial pressure. For this purpose, a daily questioner was collected from participants immediately after breakfasts over ingestion of dates and control subjects (ingesting the dates varieties' H'mira, Tinissine and Deglet Noor). However, the blood pressure was measured for all the participants.

\subsection{Statistical Analysis}

All the analyses have been done triplicate and the table values were expressed as mean \pm standard deviation. Different deviations were tested by Analysis of Variance (ANOVA). The $\mathrm{P}$ value was considered significant at $p<0.05$. The area under the glycaemia (having eaten nothing) curve is chose as base line. To compare dates effect on arterial blood pressure, we got rescue from $t$-test of student with the $p 5 \%$ and $99.9 \%$ from solver software STATISTICA (Version 6.1).

\section{Results and Discussion}

\subsection{Biochemical Characteristics of the Three Varieties of Dates}

The components of studied dates are displayed in Table 1, the three varieties match the good conservation compared with the recommendation for dates which must not be over $26 \%$ of the varieties of cane sugar and $30 \%$ for the varieties of invert sugar ${ }^{27}$; which confers good saleable value. Sugars constitute the major part of fresh fruit; they vary up to $71 \%$ for Deglet Noor, $58.6 \%$ for Tinissine and $60 \%$ for H'mira; which allot a great energetic value. The same observations on the variability of sugars rates between $60 \%$ and $80 \%$ have been made for other varieties of Algerian dates ${ }^{28}$. The strongest concentration of reducing sugars $58 \%(\mathrm{p}=0.002)$ is available in the H'mira variety versus $42.2 \%$ in Deglet Noor which is significantly $(\mathrm{p}<0.001)$ rich in sucrose. The insoluble fibers don't vary significantly between the three varieties; contrary to soluble fibers which are more important $(\mathrm{p}<0.05)$ in H'mira. Besides, the results for soluble fiber content of the three varieties (Table 1) match with other studies which report rates around 5.16 and $6.68 \%{ }^{29}$. The proteins level is higher (0.05) in Deglet Noor. Although the three varieties of dates are poor in sodium, they were rich for potassium and magnesium, coherent results comparing with literature from whatever the geographic origin ${ }^{29,30}$. According to the USDA's National Nutrient Database for standard reference release 25 , the dates have tenor higher for potassium than other common fruits or legumes consumed in the USA. The concentration of last two trace element $\left(\mathrm{K}^{+}\right.$and $\left.\mathrm{Mg}^{2+}\right)$ were more balanced $(\mathrm{p}<0.05)$ in Tinissine.

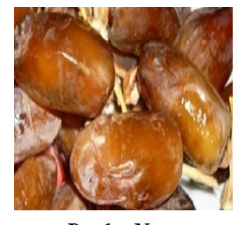

Deglet Noor

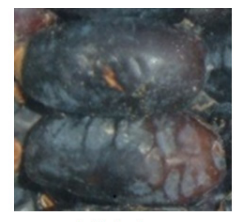

Tinissine

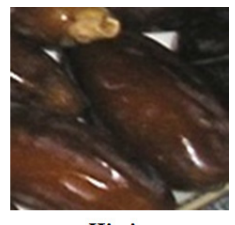

H'mira
Figure 1. Pictures of the three varieties of date. 
Table 1. Biochemical component (\%) of three varieties H'mira, Deglet Noor and Tinissine

\begin{tabular}{lcccc}
\hline & H'mira & $\begin{array}{c}\text { Deglet } \\
\text { Noor }\end{array}$ & Tinissine & Bread \\
\hline Glucose & $29.2 \pm 1.2^{\mathrm{a}}$ & $21.2 \pm 0.8^{\mathrm{b}}$ & $27.3 \pm 0.21^{\mathrm{a}}$ & Sugars \\
Fructose & $28 \pm 0.8^{\mathrm{a}}$ & $21.6 \pm 0.7^{\mathrm{b}}$ & $27 \pm 0.1^{\mathrm{a}}$ & \\
Reducing & $58.9 \pm 0.1^{\mathrm{a}}$ & $43.2 \pm 0.17^{\mathrm{b}}$ & $56.13 \pm 1^{\mathrm{a}}$ & 55.10 \\
sugars & & & \\
Sucrose & $1.2 \pm 0.09^{\mathrm{a}}$ & $28.1 \pm 0.1^{\mathrm{b}}$ & $1.8 \pm 0.05^{\mathrm{a}}$ & \\
\hline Insoluble fibers & $6.2 \pm 0.05^{\mathrm{a}}$ & $7.7 \pm 0.12^{\mathrm{a}}$ & $6.5 \pm 0.9^{\mathrm{a}}$ & \\
Soluble fibers & $7.6 \pm 0.17^{\mathrm{b}}$ & $5.5 \pm 0.04^{\mathrm{a}}$ & $6 \pm 0.01^{\mathrm{a}}$ & 3.10 \\
\hline Proteins & $2.5 \pm 0.17^{\mathrm{b}}$ & $1.52 \pm 0.09^{\mathrm{a}}$ & $1.9 \pm 0.24^{\mathrm{a}}$ & 9.00 \\
\hline Ashes & $1.97 \pm 0.01^{\mathrm{a}}$ & $1.7 \pm 0.01^{\mathrm{a}}$ & $2 \pm 0.09^{\mathrm{a}}$ & \\
Lipids & $0.63 \pm 0.11^{\mathrm{a}}$ & $0.59 \pm 0,14^{\mathrm{a}}$ & $0.61 \pm 0.2^{\mathrm{a}}$ & 0.31 \\
\hline Water content & $21.6 \pm 0.02^{\mathrm{a}}$ & $24 \pm 0.09^{\mathrm{a}}$ & $22.6 \pm 0.02^{\mathrm{a}}$ & \\
Potassium & $824 \pm 9^{\mathrm{a}}$ & $665 \pm 8.4^{\mathrm{b}}$ & $916.5 \pm 5.8^{\mathrm{c}}$ & \\
mg/100g & & & & \\
$\begin{array}{l}\text { Magnesium } \\
\text { mg/100g }\end{array}$ & $45.2 \pm 2^{\mathrm{a}}$ & $36.1 \pm 0.18^{\mathrm{b}}$ & $65.9 \pm 0.82^{\mathrm{c}}$ & \\
\hline $\begin{array}{l}\text { Different uppercase } \\
\text { statistically significant data at } 5 \%(p<0.05) .\end{array}$ & & & \\
\hline
\end{tabular}

The sodium content doesn't reach threshold detection rate for H'mira and Tinissine, $0.19 \pm 0.01 \mathrm{mg} / 100 \mathrm{~g}$ for Deglet Noor.

\subsection{Phytochemical Characteristics of the Three Varieties of Dates}

The results of phytochemical substance detection, content of polyphenols and flavonoids in the Table 2, display for the three varieties neat positive total polyphenols, flavonoids and tannins. The content of total polyphenols in the three varieties ranged between $219.75-401 \mathrm{mg} \mathrm{GAE} / 100 \mathrm{~g} \mathrm{FW}$ is high (Table 2); other studies on the Algerian dates report higher values, $510 \mathrm{mg}$ GAE/100g of extract from Deglet Noor ${ }^{31}$ and very low value $6.73 \mathrm{mg}$ GAE/100g FW for the same variety ${ }^{32}$. The flavonoids content for the three varieties does not deviate significantly.
Table 2. Characteristics of different phytochemical substances

\begin{tabular}{lccc}
\hline & H'mira & DegletNoor & Tinissine \\
\hline Alcaloids & + & + & - \\
Koumarines & ++ & ++ & ++ \\
Polyphenols & ++ & +++ & +++ \\
Tannins & +++ & ++ & +++ \\
Flavonoids & +++ & +++ & ++ \\
Polyphenols (mg & $219.75 \pm$ & $326.2 \pm 0.9$ & $401 \pm 1$ \\
GAE/100g of extract) & 1.1 & & \\
Flavonoïdes (mg & $1.98 \pm 0.6$ & $2.1 \pm 0.1$ & $2.7 \pm 0.65$ \\
QE/100g of extract) & & & \\
\hline$-:$ Absence, $+++:$ very rich,++: moderately rich, +: presence in small \\
quantities.
\end{tabular}

\subsection{Glycemic Index for the Three Varieties of Dates}

The evolution of glycaemia, after date ingestion, is compared to control glucose (Figure 2). The curves illustrate the low acclivity of blood glucose rate. This outcome of GI confirms low glycemic index (55 or less), according to the recommended clustering by Brand-Miller et al. ${ }^{33} ; 44.34 \pm 2,48 \pm 1.98$ and $52.35 \pm 3.20$ for Tinnisine, H'mira and Deglet Noor respectively, in conformity with those which have been found for the varieties from Emirat, Khalas and Bo Ma'an where the GI were 35.5 and 49.7 respectively ${ }^{34}$.

The variety Khalas added in yogurt figured out $35.5^{35}$, and Fara'd, Lulu, Bo Ma'an, Dabbas and Khalas showed GIs of $54,53.50 \pm 8.60,46.30 \pm 7.10,49.10 \pm 3.60$ and 55.10 \pm 7.70 respectively $^{36}$. The three varieties of Oman's dates have observed GI between 47.60 and $57.7^{37}$. The low GI of dates may be attributed, in some extent on the high level of fructose, nevertheless for H'mira and Tinissine. A study has argued that natural fructose from fruits has a low GI; 23 due to its hepatic metabolism ${ }^{38}$. It has also been

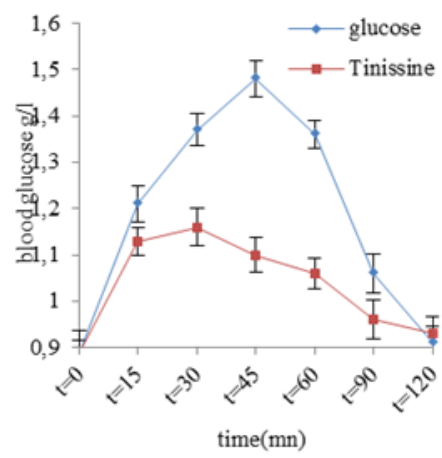

$\mathrm{me}(\mathrm{mn})$
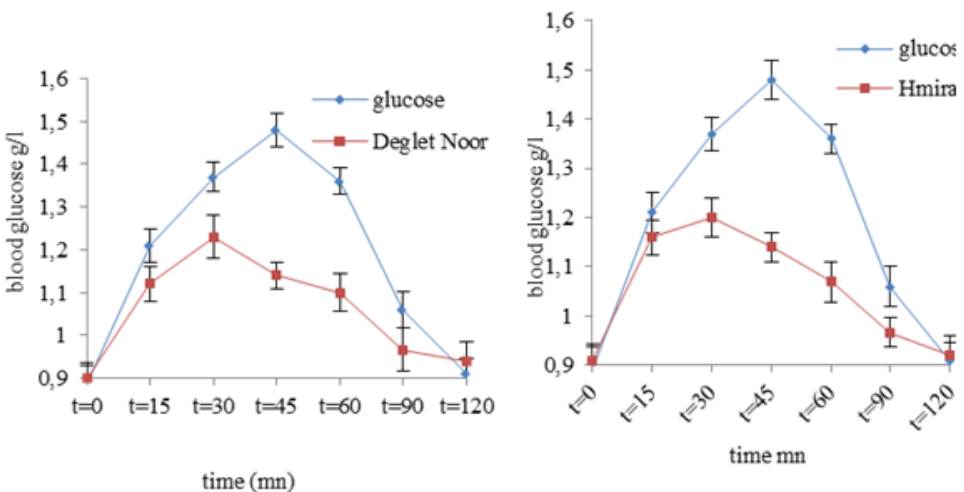

Figure 2. Kinetics of average glycaemia from the ten subjects (by $t=0)$ ), on standard glucose and test dates. 
reported, there is a negative correlation between fructose and the values of dates' $\mathrm{GI}^{37}$ and on the other hand the important tenor of soluble alimentary fiber slows down digestion and absorption of glucose moderating therefore postprandial glycaemia ${ }^{39}$ as it has been demonstrated that the alimentary fiber tenor is significantly correlated with GI of aliments ${ }^{40}$. An alimentation poor in GI can drop the risk of cardiovascular diseases, because of it allow to improve the body weight and to lower hemoglobin glycation and LDL rate ${ }^{41}$.

Besides, other studies on the dates have reported high GI, a GI tested with gestational female diabetes a mean of $61.1^{42}$, a GI for Australians dried dates had a mean of $103^{43}$. Until to date the determination of the GI of aliments are suffering of variability by either the intrinsic factors of ailments such the exact composition - origin, variety and experimental artifacts or intra-individual glycaemia response variations, which are responsible of different GI for a unique aliment ${ }^{44}$. None anomaly was detected during this study. The coherence of data is conformed to a coefficient of variance below the threshold established by the ISO $(<30 \%)$.

\subsection{Evaluation of Satiety}

The evaluation of appetite feeling with VAS is presented from Figure 3 to 6 . One can remark (Figure 3 ) that the hunger is significantly lower after dates eating compared to bread $(P=0.02)$ at $120 \mathrm{mn}$. The dates have been associated with a significant increase of measured values of repletion than bread's at 60,90 and 120 min (Figure 4). The Figures 5 and 6 display the desire to eat and alimentary consumption expectation; no significant difference is observed across the four conditions for the two appetite sensation. Within the Table 3, 0-120mn AUC for all appetite sensation tends to be lower with dates for desire to eat, hunger, alimentary consumption expectation and higher for repletion. All of these observations confirm the results of many conducted studies, over healthy subjects; who report that the aliments at low GI act on hunger from 2 to $6 \mathrm{~h}$ after their ingestion and lead to repletion ${ }^{33,45}$. Pair wise, the high sweetening potential of fructose in relation to glucose induces satiety ${ }^{46}$. The dates by their important tenor in alimentary fibers may affect the satiety. As previously argued, the fiber has the potential to slow down gastric emptying and nutrient absorption; since this is related to aliment viscosity in the gut $\operatorname{tract}^{47}$. As it has been demonstrated a positive correlation between aliment viscosity in stomach, the slowing down of gastric emptying and the sensation of repletion from human exists $^{48}$.

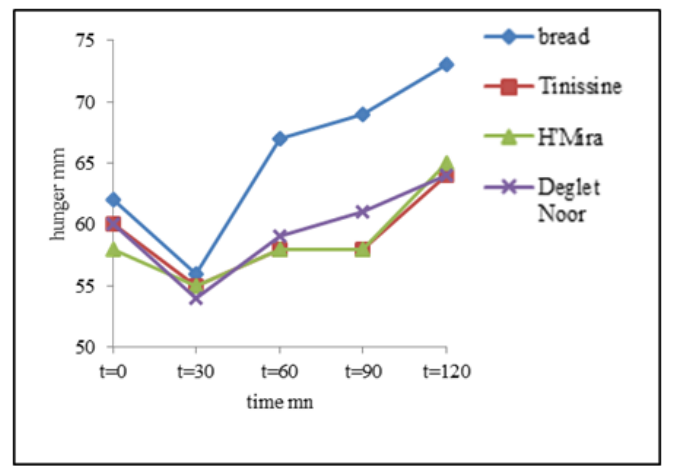

Figure 3. Change in the sensation of hunger as assessed by visual analog scale, before and after consumption of each date and bread. Each data point represents the mean of all self-assessment scores at each point.

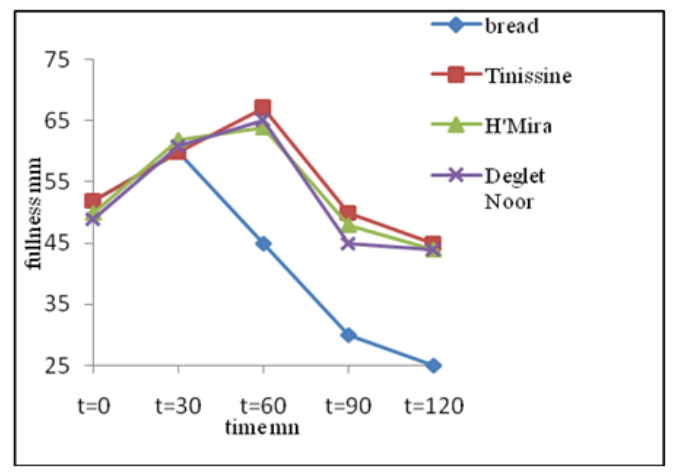

Figure 4. Change in the sensation of fullness as assessed by visual analog scale, before and after consumption of each date and bread. Each data point represents the mean of all self-assessment scores at each point.

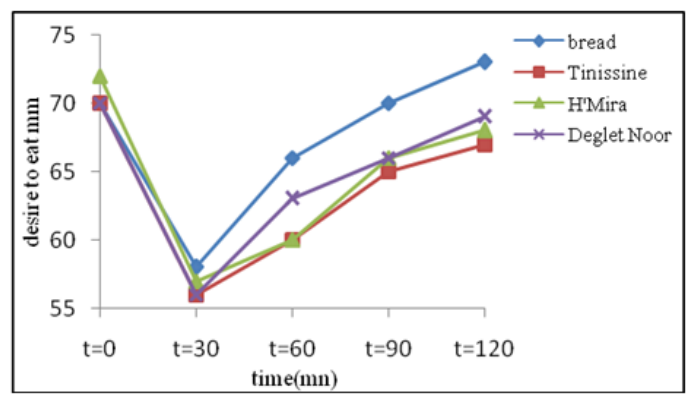

Figure 5. Change in the sensation of desire to eat as assessed by visual analog scale, before and after consumption of each date and bread. Each data point represents the mean of all selfassessment scores at each point. 
Table 3. Between-group comparisons for area under the curve; AUC0-120 $(\mathrm{mm} \times \mathrm{min})$ for each appetite sensation obtained by Visual Analog Scale (VAS)

\begin{tabular}{lccccc}
\hline & Bread & Tinissine & H'mira & DegletNoor & $p$ \\
\hline Hunger & $11055 \pm 3316,50$ & $9810 \pm 2452,50$ & $9870 \pm 2170,22$ & $9900 \pm 2403,70$ & 0,98 \\
Fullness & $6510 \pm 1492,20$ & $8895 \pm 2045,85$ & $8700 \pm 2001$ & $8520 \pm 2257,10$ & 0,90 \\
Desire to eat & $11205 \pm 3585,60$ & $10545 \pm 2636,25$ & $10710 \pm 2945,45$ & $10755 \pm 3000,21$ & 0,70 \\
Prospective food comsumption & $12705 \pm 4319,70$ & $11605 \pm 3248,45$ & $11303 \pm 3390,70$ & $11780 \pm 3270,30$ & 0,81 \\
\hline
\end{tabular}

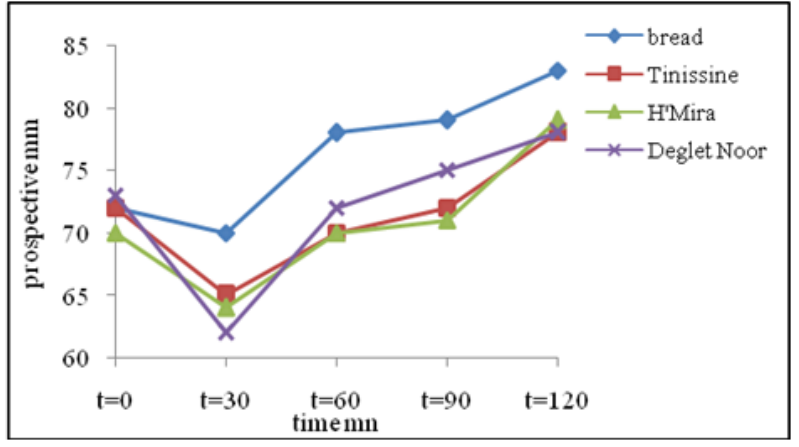

Figure 6. Change in the sensation of prospective of food consumption as assessed by visual analog scale, before and after consumption of each date and bread. Each data point represents the mean of all self-assessment scores at each point.

\subsection{The Effects on Arterial Blood Pressure}

The results of PAS and PAD from hyper and normotensive subjects are wrapped up in the Tables 4 and 5. A significant antihypertensive effect at the systolic and diastolic pressures levels are observed secondarily to each variety of dates ingestion during 21 days. This effect is more majored when it is question of hypertensive individuals, where a significant $(p<0.001)$ drop of PAS is about $9 \pm 2$ $\mathrm{mmHg}, 8.7 \pm 2.1 \mathrm{mmHg}$ and $13.1 \pm 1.67 \mathrm{mmHg}$ for H'mira, Deglet Noor and Tinissine respectively. The hypotensive issue of the dates is more marked for the PAD: it's denoted by a decrease $(p<0.001)$ of $13 \pm 3 \mathrm{mmHg}, 12.94 \pm 3 \mathrm{mmHg}$ and $15.57 \pm 3.19) \mathrm{mmHg}$ for the three precedent listed varieties respectively.

We observed a decrease of the arterial pressure in both the genders. Many works have reported that the content in dates $\left(\mathrm{Na}^{+}, \mathrm{K}^{+}, \mathrm{Mg}^{2+}\right)$ can potentially affect the arterial tension ${ }^{49}$. The supply in $\mathrm{K}^{+}$and $\mathrm{Mg}^{2+}$ coupled with a low amount of $\mathrm{Na}^{+}$is often efficient and effective treatment compared to an antihypertensive medicine ${ }^{50}$. This explains the hypotensive effect of our three varieties on the one hand and on the other hand, the decrease in pressure, greater for Tinissine (rich in potassium and poor in sodium) (Table 1). The tannins and flavonoids are recognized for their properties to raise the resistance of capillary, vein tone. They have inhibition activities

Table 4. PAS and PAD before and after consumption of dates in hypertensive subjects

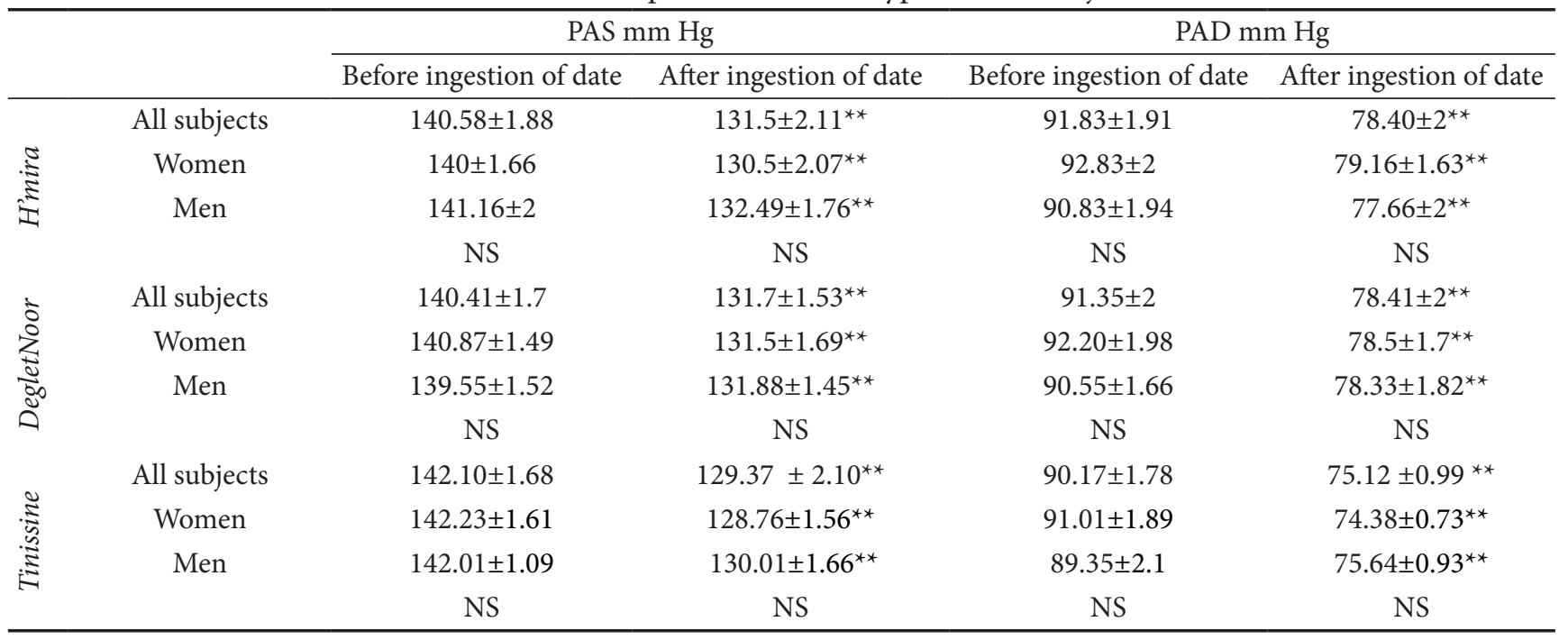

\footnotetext{
${ }^{*}$ Significant deviation between before and after dates consumption $p<0.001$ No Significant (NS) deviation between the two sexes
} 
Table 5. PAS and PAD before and after date's consumption from normotensive subjects

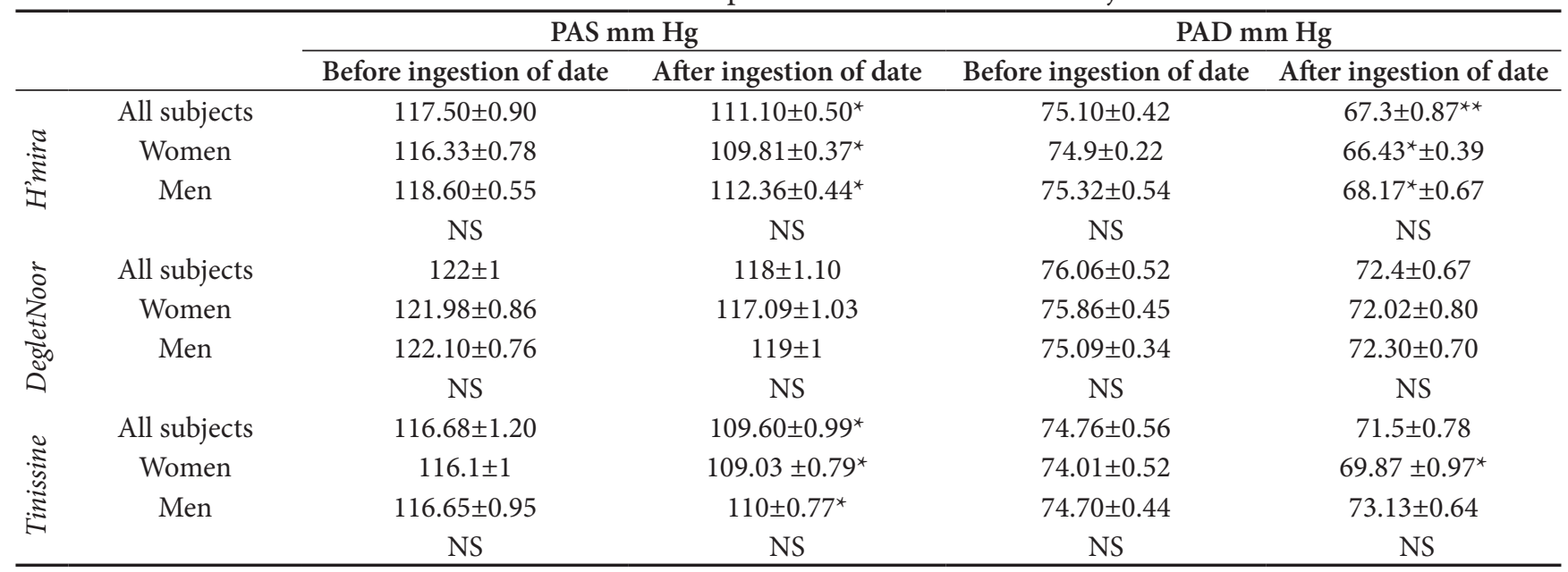

${ }^{* *}$ Significant deviation between before and after dates consumption $p<0.001$ No Significant (NS) deviation between the two sexes

of decarboxylase, elastase and angiotensin conversion enzyme $^{51}$. Polyphenols by their antioxidant property are implied in the fight against atherosclerosis and the cancers which are favorable factors for hypertension ${ }^{52}$. The presence of these last in the dates renders them beneficial for hypertensive treatment ${ }^{53}$.

\section{Conclusions}

The results gained already enable us to note that dates, like fruits (with strong nutritional interest), present a low glycemic index and ensure the sugar hemostasis is maintained. It is reminded that the control of low GI regimen is useful for the primary prevention to decrease diabetes prevalence ${ }^{54}$, as we can easily reach the satisfactory level of satiety by eating less. This study could be interest for the prevention and treatment of grade 1 arterial hypertension. It will be interesting to pursue this study by treating subjects with advanced hypertension and to document the different components of dates whose benefits don't cease to be demonstrated.

\section{References}

1. Al-shahib W, Marshall RJ. The fruit of the date palm: Its possible use as the best food for the future. Int J Food Sci Nutr. 2003; 54:247-59.

2. Hassan NS, Amom ZH, Al-Mokhtarrudin N, Esa NM, Azlan A. Nutritional composition and in-vitro evaluation of the antioxidant properties of various dates extracts (Phoenix dactylifera L.) from Libya. Asian J Clin Nutr. 2010; 2:208-14.
3. Jenkins DJ, Wolever TM, Taylor RH, Barker H, Fielden H, Baldwin JM, Bowling AC, Newman HC, Jenkins AL, Goff DV. Glycemic index of foods: a physiological basis for carbohydrate exchange. Am J Clin Nutr. 1981; 34:362-6.

4. Brand-Miller JC, Foster-Power K, Atkinson F. The shopper's guide to GI values: the authoritative source of glycemic index values for more than 1,200 foods. DA CAPO PRESS. 2015. p. 253.

5. WHO. International society of hypertension guidelines for the management of hypertension. Blood Pressure. 1999; 1:9-43.

6. Opperman AM, Venter CS, Oosthuizen W, Thompson RL, Vorster HH. Meta-analysis of the health effects of using the glycaemic index in meal-planning. British Journal of Nutrition. 2004; 92:367-81.

7. Brand-Miller JC, Hayne S, Petocz P, Colagiuri S. Low-glycemic index diets in the management of diabetes: a meta-analysis of randomized controlled trials. Diabetes Care. 2003; 26:22-61.

8. Rizkalla S, Belliste F, Slama G. Health benelits of low glycaemic index foods, such as pulses in diabetic patients and health individuals. Br J Nutr. 2002; 38:S255-62.

9. Rock W, Rosenblat M, Borochov-Neori H, Volkova N, Judeinstein S, Elias M, Aviram M. Effects of date (Phoenix dactylifera L., Medjool or Hallawi Variety) consumption by healthy subjects on serum glucose and lipid levels and on serum oxidative status: a pilot study. J Agri Food Chem. 2009; 57:8010-7.

10. German JB, Walzem RL. The health benefits of wine. Annu Rev Nutr. 2000; 20:561-93.

11. Delbarre B, Delbarre G. Hypertension artérielle: physiopathologie et pharmacologie, Edition Masson; Paris: 1993.

12. Duffy SJ, Gokce N, Holbrook M. Treatment of hypertension with ascorbic acid. Lancet. 1999; 354:2048-9.

13. Vasdev S, Gill V, Parai S, Longerichand L, Gadag V. Dietary vitamin $\mathrm{E}$ and $\mathrm{C}$ supplementation prevents fructose induced hypertension in rats. Molecular and Cellular Biochemistry. 2002; 241; 107-14. 
14. Audigie CL. Manipulation d'analyse biochimique. Ed. Doin; Paris: 1978. p. 27-74.

15. AFNOR. Dosage de l'azote en vue du calcul de la teneur en protéines brutes. NFV 18-100. Association Française de Normalisation, Paris-La Défense. 1977a.

16. AFNOR. Produits agricoles et alimentaires. Détermination de la cellulose brute, méthode générale. NF V 03-040. Association Française de Normalisation, Paris-La Défense. 1993.

17. Multon JL. Techniques d'analyse et de contrôle dans les industries agro-alimentaires. Analyse des constituants alimentaires. 1991; 4:121-37.

18. AFNOR. Dosage des cendres brutes. NF V 18-101. Association Française de Normalisation, Paris-La Défense. 1977b.

19. Owen PL, Johns T. Xanthine oxidase inhibitory activity of north eastern North American plant remedies used for gout. Journal of Ethnophrmacology. 1999; 64:149-60.

20. Ciulei I. Practical manuals on the industrial utilization of chemical and aromatic plants. Methodology for Analysis of Vegetable Drugs. Ministry of Chemical Industry, Bucharest. 1982.

21. Boizot N, Charpentier JP. Méthode rapide d'évaluation du contenu en composés phénoliques des organes d'un arbre forestier. Cahier des Techniques de l'INRA Bulletin de Liaison Interne. 2006. p. 79-82.

22. Lamaison JL, Carnat A. Teneurs en principaux flavonoïdes des fleurs et des feuilles de Crataegus monogyna Jacq. Et de Crataegus laevigata (Poiret) DC., en fonction de la végétation. Plants Medicinal Phytother. 1991; 25:12-6.

23. Brouns F, Bjorck I, Frayn K, Gibbs A, Lang V, Slama G, Wolever TMS. Glycaemic index methodology. Nutr Res Rev. 2005; 18:145-71.

24. Drouin P, Blickle JF, Charbonnel B, Eschwege E, Guillausseau PJ, Plouin PF, Daninos JM, Balarac N, Sauvanet JP. Diagnostic et classification du diabète sucré; les nouveaux critères. Rapport des experts de l'ALFEDIAM. Diabetes Metab. 1999; 25:72-83.

25. Blundell JE, De Graaf K, Finlayson G, Halford JCG, Hetherington M, King N, Stubbs J. Measuring food intake, hunger, satiety, and satiation in the laboratory, Chapter 8 . In: Allison DB, Baskin ML (Eds). Handbook of assessment methods for eating behaviors and weight-related problems: measures, theory and research. 2nd Ed. SAGE Publications Inc; 2009. p. 283-325.

26. Chamontin B. Hypertension Artérielle de l'adulte. La Revue du Praticien. 2001; 51:1697-713.

27. ECE. NORME CEE-ONU DDP-08 concernant la commercialisation et le contrôle de la qualité commerciale des Dattes. 2010.

28. Acourene S, Buelguedj M, Tama M, Taleb B. Caractérisation, évaluation de la qualité de la datte et identification des cultivars rares de palmier dattier de la région des Ziban. Revue. Recherche Agronomique. 2001. p. 19-39.

29. Elleuch M, Besbes S, Roiseux O, Blecker C, Deroanne C, Drira NE, Attia H. Date flesh: chemical composition and characteristics of the dietary fibre. Food Chem. 2008; 111:676-82.
30. Ismail B, Haffar I, Baalbaki R, Mechref Y, Henry J. Physico-chemical characteristics and total quality of five date varieties grown in the United Arab Emirates. Int J Food Sci Technol. 2006; 41:919-26.

31. Khali M, Selselet-Attou G. Effect of heat treatment on Polyphenol oxidase and peroxidase activities in Algerian stored dates. Afr J Biotechnol. 2007; 6:790-4.

32. Mansouri AG, Embared E, Kokkalou E, Kefalas P. Phenolic profile and antioxidant activity of the Algerian ripe date palm fruit (Phoenix dactylifera L.). Food Chem. 2005; 89:411-20.

33. Brand-Miller JC, Allwan C, Mehalski K, Brooks D. The glycaemic index of further Australian foods. Proc Nutr Soc. 1998; 22:110.

34. Miller J, Dunn E, Hashim I. Glycemic index of 3 varieties of dates. Saudi Med J. 2002; 23:536-8.

35. Miller J, Dunn E, Hashim I. The glycaemic index of dates and date/yoghurt mixed meals. Eur J Clin Nutr. 2003; 57:427-30.

36. Alkaabi J, Al-Dabbagh B, Ahmad S, Saadi H, Gariballa S, Ghazali MA. Glycemic indices of five varieties of dates in healthy and diabetic subjects. Nutr J. 2011; 10:59.

37. Ali AYS, Al-kindi M, Al-said F. Chemical composition and glycemic index of three varieties of Omani dates. Int J Food Sci Nutr. 2009; 60(suppl.4):51-62.

38. Foster-Powell K, Brand-Miller JC. International tables of glycemic index. Am J Clin Nutr. 1995; 62(suppl):871S-93S.

39. Meyer KA, Kushi LH, Jacobs JR, Meyer KAL, Kushi LH, Jacobs JR, Slavin J, Sellers TA, Folsom AR. Carbohydrates, dietary fiber and incident type 2 diabetes, in older women. Am J Clin Nutr. 2000; 71:921-30.

40. Wolever TMS. The glycemic index. World Rev Nutr Diet. 1990; 62:120-85.

41. Liu S, Liu WC, Willett M, Stampfer J, Frank B, Hu M, Franz L, Sampson C, Hennekens H, Manson JE. A prospective study of dietary glycemic load, carbohydrate intake, and risk of coronary heart disease in U.S. women. Am J of Clin Nutr. 2000; 71:1455-61.

42. Lock D, Bar-Eyal A, Voet H, Madar Z. Glycemic indeces of different foods given to pregnant diabetic subjects. Obstetric Gynecology. 1988; 71:180-3.

43. Foster-Powell K, Holt SHA, Brand-Miller JC. International table of glycemic index and glycemic load values. Am J Clin Nutr. 2002; 76:5-56.

44. Wolever TMS, Vorster HH, Bjorck I, Brand-Miller JC, Brighenti F, Mann JI, Ramdath DD, Granfeldt Y, Hol S, Perry TL, Venter C, Xiaomei WU. Determination of the glycemic index of food sinter laboratory study. Inter laboratory study. Eur J Clin Nutr. 2003; 57:475-82.

45. Leathwood P, Pollet P. Effects of slow release carbohydrates in the form of bean flakes on the evolution of hunger and satiety in man. Appetite. 1988; 10:1-11.

46. Al-farsi M, Alasalvar C, Morris A, Baron M, Shahidi F. Compositional and sensory characteristics of three native sun-dried date (Phoenix dactylifera L.) varieties grown in Oman. J Agric Food Chem. 2005; 53:7586-91. 
47. Malkki Y. Physical Properties of dietary fiber as keys to physiological functions. American Association of Cereal Chemists, Inc. 2001; 46:196-9.

48. Marciani L, Gowland PA, Spiller RC, Manoj P, Pretima M, Moore RJ, Young P, Al-Sahab S, Bush D, Wright J, Fillery-Travis AJ. Gastric response to increased meal viscosity assessed by echo-planar magnetic resonance imaging in humans. The Journal of Nutrition. 2000; 130:122-7.

49. Kotchen TA, Mc Carron DA. Dietary electrolytes and blood pressure: a statement for healthcare professionals from the American Heart Association Nutrition Committee. Circulation. 1998; 98:613-7.

50. Houston M. The role of magnesium in hypertension and cardiovascular disease. J Clin Hypertens. (Greenwich). 2011; 13:843-7.

51. Bruneton J. Pharmacognosie, phytochimie, plantes médicinales. 4e ed. Lavoisier Paris. 2009.
52. Chevalley I, Marston A, Hostettmann K. New phenolic radical scavengers from Saxifragacuneifolia. Pharmaceut Biol. 2000; 38:222-8.

53. Tahraoui A, El-Hilaly J, Israili ZH and Lyoussi B. Ethnopharmacological survey of plants used in the traditional treatment of hypertension and diabetes in South-Eastern Morocco (Errachidia province). J Ethnopharmacol. 2007; 110:105-17.

54. Tuomilehto J, Lindström J, Eriksson JG, Valle TT, Hämäläinen H, Ilanne-Parikka P, Keinänen-Kiukaanniemi S, Laakso M, Louheranta A, Rastas M, Salminen V, Uusitupa M. Finnish diabetes prevention study group. Prevention of type 2 diabetes mellitus by changes in lifestyle among subjects with impaired glucose tolerance. N Engl J Med. 2001 May 3; 344(18):1343-50. 